\title{
Relationship Between Psychiatric Nurses' Resilience and Empathic Tendencies
}

\author{
Nareg Doğan ${ }^{1} \mathbb{D}$, Nur Elçin Boyacıoğlu \\ ${ }^{1}$ Bezmialem Vakıf University, Faculty of Health Sciences, Nursing Department, Istanbul \\ ${ }^{2}$ Istanbul University-Cerrahpasa, Faculty of Health Sciences, Department of Gerontology, Istanbul \\ Correspondence Author: Nur Elçin Boyacıoğlu \\ E-mail: nur.boyacioglu@istanbul.edu.tr \\ Received: $06.04 .2020 \quad$ Accepted: 28.04 .2021
}

\begin{abstract}
Objective: Resilience associated with empathy and increases nurses' job satisfaction and reduces burnout. This study aimed to determine the relationship between resilience and empathic tendencies of nurses working in the psychiatry service.

Methods: This study is descriptive and correlational. The study was conducted with 101 nurses working in a psychiatric state hospital between May 2017 and June 2017. Study data were collected using an information form, Resilience Scale for Adults, and Empathic Tendency Scale. Statistical analysis was conducted using frequency, mean, Pearson's and Spearmen's correlation analyses, and linear regression analysis.

Results: Nurses' resilience and empathic tendencies were above the median (126.84 \pm 16.09$)$ and $70.03 \pm 7.89)$, respectively. A positive, weakmoderate level, linear relationship was found between the scores of resilience and empathic tendency scales. A linear relationship was found between empathic tendency and perception of future, social competence, and social resources. No linear relationship was found between structured style, perception of self, or family cohesion. Multiple linear regression analysis found that the social competence subscale was the variable that predicted the Empathic Tendency Scale score.

Conclusion: The study detected that psychiatric nurses social competence, a subscale of resilience, was effective in the nurses' empathic tendencies. It is recommended to improve nurses' social competences through practices that will improve the quality of the interaction between the patient and nurse, and nurses' empathy and resilience, which have significant effects on the patients' recovery time.

Keywords: Job Satisfaction, Empathy, Psychiatric Nursing, Regression Analysis
\end{abstract}

\section{INTRODUCTION}

Nursing is a health discipline that experiences intense human to human relationships. It requires providing compassionate care in a therapeutic relationship with the patient and teamwork (1). However, nurses may become vulnerable to several traumatic and stressful events directly or indirectly while providing care. In addition, there are various stressful events particular to the field of psychiatry. Psychotic symptoms include patient behaviors that could cause conflict, domestic violence, suicide attempts, verbal/physical violence committed to self or others and having potential to harm self and others and coercive restraint practices applied to these behaviors (2-4). These stressful situations originating from the profession cause nurses to feel guilt, burnout, affective disharmony, post-traumatic stress, low levels of job and life satisfaction, and depression and cause them to leave their job $(1,3,5,6)$. Psychiatric nurses who provide care to traumatized patients are indirectly traumatized and are at risk of secondary traumatic stress (7).
Adverse events experienced in psychiatry may negatively affect the caregiver role of psychiatric nurses. Psychiatric nurses should maintain their caregiver role in spite of risky situations. Thus, recently, traditional understanding of care has been extended and the concept of resilience has been included $(3,8)$. Nurses' resilience and ability to turn bad experiences into good experiences during the therapeutic relationship process sets a positive example for patients (3).

Resilience is a significant characteristic that causes one to pull themselves together against stressful life events. Resilience, which is a personal characteristic and a dynamic process, includes control and management of positive and negative emotions (9). Descriptions regarding resilience include different features of this concept. Earvolino Ramirez (10) defines resilience as individuals' pulling themselves together against bad situations, which means changing back to their former state after depression or injuries. 
Psychiatric nurses are considered a "resilient group" because they professionally undergo several changes and developmental processes to cope with adverse situations. Resilience is defined as "the capacity of resisting difficulties and continuing to positively develop against change" (11). Resilience has several effects on psychiatric nurses' working lives. It is a significant factor regarding job and life satisfaction, self-reliance, burnout, and depression (1,3,9,12,13). Resilience decreases the act of leaving a job, is effective in managing a high level of stress, and increases job and life satisfaction $(9,12,13)$. Mealer et al. (13) found that a high level of resilience in nurses prevents them from having posttraumatic stress disorder, anxiety, depression, and burnout.

The literature presents different opinions and outcomes regarding the relationship between empathy and resilience $(9,17-20)$. Resilience is associated with difficulties, stressful situations, and post-traumatic growth. The growth resulting from stressful, traumatic situations develops with increasing helping behavior, compassion, self-sacrifice, commitment, and empathy in the individual. Some studies indicate that concepts of resilience and empathy mutually affect each other (9,14-17). Empathy is among the factors affecting resilience. Resilient individuals fulfill their duties in spite of the difficulties in their job, and they empathically and willingly continue to provide care (3). In spite of their challenging working conditions, psychiatric nurses should be resilient so they can use their professional patient care skills, cope with challenging situations, and work empathically and willingly (1).

Psychiatric nurses are expected to provide optimum care in spite of the traumatic situations they experience in their troubled and stressful working lives. Thus, resilience levels of psychiatric nurses, risks, and preventive factors affecting their resiliency should be known.

The literature includes studies regarding nurses' resilience $(1,3,8,11-13,21,22,24-26)$. However, no study examining the relationship between resilience and empathic tendency, which is considered a preventive factor of resilience, was found. This study aimed to determine the relationship between resilience and empathic tendencies of the nurses working in a psychiatry service, and answers were sought for the following questions:

1. What are the resilience levels of psychiatric nurses?

2. What are the empathic tendency levels of psychiatric nurses?

3. Is there a linear relationship between resilience and empathic tendencies of psychiatric nurses?

\section{METHODS}

\subsection{Study Design and Sample}

This study was descriptive and correlational. The study used the random sampling method of the improbable sampling methods and aimed to reach the entire population. Study data were collected between May 2017 and June 2017. Of the 200 nurses working in the psychiatry clinics in a Psychiatry Hospital in İstanbul, the study was conducted with 117 nurses who volunteered to participate in the study. All complete and whole questionnaires - 101 questionnaires - were evaluated (response rate of 58.5\%). Study Inclusion Criteria included working in the psychiatry clinic of the relevant hospital and volunteering to participate in the study.

\subsection{Data Collection Tools}

Study data were collected using a Personal Information Form (8 items), Empathic Tendency Scale (20 items), and Resilience Scale for Adults (33 items).

2.2.1. Personal Information Form: It included eight questions regarding variables such as nurses' age, gender, marital status, education, position (nurse supervisor, service nurse), general shifts, working place, and years of experience. The questions on the form were multiple-choice.

2.2.2. Empathic Tendency Scale (ETS): The ETS developed by Dökmen in 1988 aims to measure the individuals' potential to develop empathy in daily life (27). This 5-Likert-type scale (1=totally agree, 2=quite agree, 3=neutral, 4=quite disagree, 5=totally disagree) includes 20 items. The range of the scale is between 20 and 100. A higher total score indicates a higher empathic tendency. Dökmen (27) found the total Cronbach's Alpha value of the scale 0.82 , whereas this study found it was 0.72 .

2.2.3. Resilience Scale for Adults (RSA): Basım and Çetin (28) conducted the Turkish validity and reliability study of the RSA developed by Friborg et al. (29) in 2003. This scale includes six subscales, which are 'perception of self" $(1,7,13,19,28,31)$, 'perception of future' $(2,8,14,20)$, 'structured style' $(3,9,15,21)$, 'social competence' $(4,10,16,22,25,29)$, 'family cohesion' $(5,11,17,23,26,32)$, and 'social resources' $(6,12,18,24,27,30,33)$ $(28,29)$. This is a 5 -Likert type scale. If increasing resilience is associated with increasing scores, response boxes should be evaluated left-to-right as 12345 . Considering this, questions numbered 1-3-4-8-11-12-13-14-15-16-23-24-25-2731-33 would be reverse questions. However, if increasing resilience is associated with the decreasing scale scores, response boxes should be evaluated as 54321 and the reverse questions would be 2-5-6-7-9-10-17-18-19-20-21-2226-28-29-30-32. Response boxes in this study were evaluated left-to-right. Both the original scale (25) and this study found the total Cronbach's Alpha coefficient to be 0.86 .

\subsection{Procedure}

The potential participants were provided with verbal and written details regarding the study, including the choice to remove themselves from the study at any time (conformity with the Helsinki Declaration Principles). While the researchers explained the study to potential participants, they received support from a colleague (MAD) at the institution where the study was conducted. Written, informed consent was obtained from the final participants. 
Data was collected through one on one face to face interviews that took approximately 20-30 minutes. The researchers conducted the interviews in a suitable physical environment that ensured a comfortable and effective interview. The study was conducted in a separate closed room so that the interview could not be interrupted (in the policlinic room where the patient examination is not performed or in the ward manager's room).

\subsection{Ethical Considerations}

Ethical permission was granted from the ethics committee of the hospital where the study was conducted (Dr. Mazhar Osman Mental Health and Neurology Training and Research Hospital, Date/Issue/Decree no:02.02.2017-4255-624). Written and verbal informed consent was obtained from the participants. This study was conducted in accordance with the principles of the Declaration of Helsinki.

\subsection{Data Analysis}

Study data were analyzed using IBM SPSS version 21.0 (IBM Corp. Released Armonk, NY, USA) package program. Descriptive statistics were presented as mean, standard deviation (SD), median, interquartile range (IQR), minimum (min), maximum (max), frequency, and percentage. Continuous variables' suitability to normal distribution was examined using the Shapiro-Wilk Test. Intergroup comparisons of continuous variables were conducted with independent samples t-test. The linear relationship between variables was evaluated with Pearson's and Spearman's correlation tests. Based on correlations simple linear regression analysis was used to determine the relationship size regarding the subscales of "Resilience" that were thought to affect the ETS score. ETS was introduced as the dependent variable and subscales of "Resilience" as independent variables. Simple linear regression analysis was used to determine the subscale scores of the RSA that significantly predicted the ETS score. Variables with a p-value of $<0.25$ in simple linear regression analysis were included in the multi-model as candidate variables. Enter method was used in multiple linear regression analysis. The significance level was set at $p<0.05$.

\section{RESULTS}

\subsection{Individual Characteristics}

The study included 101 nurses and of these nurses, $64.4 \%$ $(n=65)$ were female, $35.6 \%(n=36)$ were male. The median age was 35 (IQR=10.5) ( $\min =22 ; \max =60)$ years and $14.9 \%$ $(n=15)$ were high school graduates, $71.2 \%(n=72)$ had a bachelors' degree, and $13.9 \%(n=14)$ had a post-graduate degree. The median years the nurses' worked in psychiatry clinics was $6(\mathrm{IQR}=8)(\min =1 ; \max =36)$. Of the nurses, $89.1 \%$ $(n=90)$ were service nurses and $87.1 \%$ were working in acute services.

\subsection{Characteristics Regarding Resilience and Empathic Tendency}

Nurses' mean empathic tendency score was 70.03 (SD=7.89) (58\% of them above average). Their mean resilience score was 126.84 (SD=16.09) (64\% of them above average) (Table I).

Table 1. Mean Empathic Tendency Scale (ETS) and Resilience Scale for Adults (RSA) Scores ( $N=101)$

\begin{tabular}{|l|l|}
\hline Scale and Subscales & Mean \pm Standard Deviation \\
\hline ETS Total & $70.03 \pm 7.89$ \\
\hline RSA Total & $126.84 \pm 16.09$ \\
\hline Structured Style & $14.08 \pm 3.32$ \\
\hline Perception of Future & $15.16 \pm 3.61$ \\
\hline Family Cohesion & $22.23 \pm 5.04$ \\
\hline Perception of Self & $21.87 \pm 3.95$ \\
\hline Social Competence & $19.58 \pm 3.49$ \\
\hline Social Resources & $28.86 \pm 4.52$ \\
\hline
\end{tabular}

No linear relationship was found between nurses' resilience scores and age $\left(r_{s}=0.130, p=0.195\right)$ or their working years $\left(r_{s}=0.071, p=0.481\right)$. The nurses obtained the highest score from the "social resources" subscale among the resilience subscales (mean=28.86, SD=4.52) (Table I).

As nurses' working years increased, empathic tendency scores significantly increased on a weak level $\left(r_{s}=0.247\right.$, $\mathrm{p}=0.013$ ). However, no significant linear relationship was found between nurses' empathic tendency scores and their age $\left(r_{s}=0.120, p=0.230\right)$.

No statistically significant intergroup difference was found between nurses' resilience and ETS scores based on their gender, education level, status, or shifts (night, day) (Table II).

Nurses' scores for resilience and structured style, family cohesion, and perception of self were significantly different based on their marital status. Married nurses' scores for resilience, structured style, family cohesion, and perception of self were significantly higher than single nurses were (Table II). 
Table 2. Comparison of resilience and empathic tendency scores based on sociodemographic characteristics $(N=101)$

\begin{tabular}{|c|c|c|c|c|c|c|c|c|c|}
\hline \multirow{3}{*}{. } & 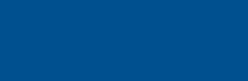 & $\begin{array}{c}\text { Empathic } \\
\text { Tendency Scale }\end{array}$ & \multicolumn{7}{|c|}{ Resilience Scale for Adults (RSA) } \\
\hline & & ETS Total & RSA Total & Structured Style & $\begin{array}{l}\text { Perception of } \\
\text { Future }\end{array}$ & $\begin{array}{l}\text { Family } \\
\text { Cohesion }\end{array}$ & $\begin{array}{l}\text { Perception of } \\
\text { Self }\end{array}$ & $\begin{array}{c}\text { Social } \\
\text { Competence }\end{array}$ & Social Resources \\
\hline & & MeantSD & MeantSD & MeantSD & MeantSD & MeantSD & Mean $\pm S D$ & Mean $\pm S D$ & Mean $\pm S D$ \\
\hline \multirow{3}{*}{ } & Female & $69.56 \pm 7.62$ & $127.75 \pm 15.16$ & $14.20 \pm 3.51$ & $15.23 \pm 3.67$ & $21.92 \pm 5.29$ & $21.60 \pm 3.52$ & $19.98 \pm 3.20$ & $29.36 \pm 3.75$ \\
\hline & Male & $70.89 \pm 8.40$ & $125.19 \pm 17.73$ & $13.86 \pm 2.98$ & $15.05 \pm 3.52$ & $22.80 \pm 4.56$ & $22.36 \pm 4.64$ & $18.86 \pm 3.89$ & $27.94 \pm 5.58$ \\
\hline & $\begin{array}{l}\text { Statistical Analysis* } \\
\text { Possibility }\end{array}$ & $\mathrm{t}:-0.80, \mathrm{p}: 0.424$ & $\mathrm{t}: 0.76, \mathrm{p}: 0.447$ & $\mathrm{t}: 0.48, \mathrm{p}: 0.626$ & $\mathrm{t}: 0.23, \mathrm{p}: 0.816$ & $\begin{array}{l}\mathrm{t}:-0.84 \\
\mathrm{p}: 0.402\end{array}$ & $\mathrm{t}:-0.92, \mathrm{p}: 0.357$ & $\mathrm{t}: 1.56, \mathrm{p}: 0.122$ & $\mathrm{t}: 1.52, \mathrm{p}: 0.130$ \\
\hline \multirow{3}{*}{ 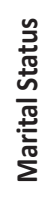 } & Married & $71.30 \pm 7.34$ & $129.76 \pm 16.68$ & $14.88 \pm 3.23$ & $15.50 \pm 3.44$ & $23.13 \pm 4.98$ & $22.84 \pm 3.54$ & $19.54 \pm 3.52$ & $29.22 \pm 4.34$ \\
\hline & Single & $68.26 \pm 8.37$ & $122.73 \pm 14.41$ & $12.95 \pm 3.16$ & $14.69 \pm 3.80$ & $20.97 \pm 4.89$ & $20.50 \pm 4.12$ & $19.64 \pm 3.49$ & $28.35 \pm 4.76$ \\
\hline & $\begin{array}{l}\text { Statistical Analysis* } \\
\text { Possibility }\end{array}$ & $\mathrm{t}: 1.93, \mathrm{p}: 0.056$ & $\mathrm{t}: 2.20, \mathrm{p}: 0.030$ & $\mathrm{t}: 2.98, \mathrm{p}: 0.004$ & $\mathrm{t}: 1.12, \mathrm{p}: 0.263$ & $\begin{array}{l}\mathrm{t}: 2.16, \mathrm{p}: \\
0.033\end{array}$ & $t: 3.06, p: 0.003$ & $\mathrm{t}:-0.14, \mathrm{p}: 0.887$ & $\mathrm{t}: 0.94, \mathrm{p}: 0.347$ \\
\hline \multirow{3}{*}{ 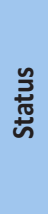 } & Nurse Supervisor & $71.70 \pm 6.61$ & $124.30 \pm 17.56$ & $12.70 \pm 3.62$ & $13.50 \pm 4.11$ & $22.50 \pm 4.06$ & $21.80 \pm 3.04$ & $20.40 \pm 3.09$ & $28.60 \pm 4.69$ \\
\hline & Nurse & $69.77 \pm 8.04$ & $126.92 \pm 15.97$ & $14.25 \pm 3.28$ & $15.30 \pm 3.50$ & $22.16 \pm 5.16$ & $21.87 \pm 4.07$ & $19.43 \pm 3.50$ & $28.86 \pm 4.54$ \\
\hline & $\begin{array}{l}\text { Statistical Analysis* } \\
\text { Possibility }\end{array}$ & $\mathrm{t}: 0.72, \mathrm{p}: 0.468$ & $\mathrm{t}:-0.48, \mathrm{p}: 0.627$ & $\begin{array}{c}\mathrm{t}:-1.40, \mathrm{p}: \\
0.163\end{array}$ & $\mathrm{t}:-1.51, \mathrm{p}: 0.133$ & $\begin{array}{c}\mathrm{t}: 0.19, \mathrm{p}: \\
0.844\end{array}$ & $\mathrm{t}:-0.05, \mathrm{p}: 0.954$ & $\mathrm{t}: 0.83, \mathrm{p}: 0.405$ & $\begin{array}{l}\mathrm{t}:-0.17 \\
\mathrm{p}: 0.861\end{array}$ \\
\hline \multirow{3}{*}{ 走 } & Day & $69.79 \pm 8.33$ & $126.70 \pm 16.95$ & $13.87 \pm 3.35$ & $14.85 \pm 3.71$ & $22.59 \pm 4.79$ & $21.98 \pm 4.25$ & $19.33 \pm 3.57$ & $29.22 \pm 4.32$ \\
\hline & Night & $70.46 \pm 6.63$ & $126.53 \pm 13.48$ & $14.73 \pm 3.25$ & $15.88 \pm 3.15$ & $21.07 \pm 5.66$ & $21.53 \pm 3.07$ & $20.07 \pm 3.14$ & $27.73 \pm 5.00$ \\
\hline & $\begin{array}{l}\text { Statistical Analysis* } \\
\text { Possibility }\end{array}$ & $\mathrm{t}:-0.36, \mathrm{p}: 0.714$ & $\mathrm{t}: 0.04, \mathrm{p}: 0.964$ & $\begin{array}{c}\mathrm{t}:-1.12, \mathrm{p}: \\
0.265\end{array}$ & $\mathrm{t}:-1.26, \mathrm{p}: 0.209$ & $\begin{array}{l}\mathrm{t}: 1.32, \mathrm{p}: \\
0.189\end{array}$ & $\mathrm{t}: 0.49, \mathrm{p}: 0.623$ & $\mathrm{t}:-0.93, \mathrm{p}: 0.352$ & $\mathrm{t}: 1.45, \mathrm{p}: 0.148$ \\
\hline \multirow{3}{*}{ 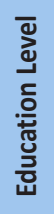 } & High School & $71.53 \pm 6.96$ & $122.86 \pm 18.04$ & $14.13 \pm 3.70$ & $14.73 \pm 3.26$ & $21.40 \pm 4.61$ & $21.40 \pm 4.61$ & $18.53 \pm 3.92$ & $27.26 \pm 5.72$ \\
\hline & University & $69.77 \pm 8.05$ & $127.53 \pm 15.73$ & $14.06 \pm 3.28$ & $15.24 \pm 3.67$ & $22.38 \pm 5.12$ & $22.38 \pm 5.12$ & $19.76 \pm 3.40$ & $29.13 \pm 4.25$ \\
\hline & $\begin{array}{l}\text { Statistical Analysis* } \\
\text { Possibility }\end{array}$ & $\mathrm{t}: 0.79, \mathrm{p}: 0.430$ & $\mathrm{t}:-1.03, \mathrm{p}: 0.302$ & $\mathrm{t}: 0.06, \mathrm{p}: 0.946$ & $\mathrm{t}:-0.50, \mathrm{p}: 0.615$ & $\begin{array}{c}\mathrm{t}:-0.69, \mathrm{p}: \\
0.488\end{array}$ & $\mathrm{t}: 0.77, \mathrm{p}: 0.442$ & $\mathrm{t}:-1.26, \mathrm{p}: 0.208$ & $\begin{array}{c}\mathrm{t}:-1.49, \mathrm{p}: \\
0.139\end{array}$ \\
\hline
\end{tabular}

$S D=S t a n d a r d$ Deviation, *Indepedent Sample- $t$ 


\subsection{The Relationship Between Resilience and Empathic Tendency}

A positive, weak-moderate, linear relationship was found between the scores of resilience and ETS $\left(r_{s}=0.371, p<0.001\right)$ (Table III). A significant linear relationship was found between three subscales (perception of future, social competence, and social resources). However, no significant linear relationship was found for the other three subscales (structured style, perception of self, and family cohesion).

Table 3. The linear relationship between resilience and empathic tendency scores $(N=101)$

\begin{tabular}{|l|l|}
\hline & ETS Total \\
\hline & $\mathrm{r}$ \\
\hline ETS Total & \\
\hline RSA Total & $0.371^{* * *}$ \\
\hline Structured Style & 0.039 \\
\hline Perception of Future & $0.238^{*}$ \\
\hline Family Cohesion & 0.122 \\
\hline Perception of Self & 0.192 \\
\hline Social Competence & $0.427^{* * *}$ \\
\hline Social Resources & $0.253^{*}$ \\
\hline
\end{tabular}

$r=$ Pearson's correlation coefficient; ${ }^{*} p<0.05,{ }^{* *} p<0.01,{ }^{* * *} p<0.001$, ETS: Empathic Tendency Scale, RSA: Resilience Scale for Adults

Simple linear regression analysis found the $p$-value regarding the relationship between the "Structured Style" subscale and ETS scores was $>0.25$. Therefore, the "Structured Style" subscale score was not included in the multiple regression analysis. Among the other 5 subscales included in the multiple linear regression analysis, only the "social competence" subscale score significantly predicted the ETS score $(p<0.05)$. There was a significant positive and weak-moderate level of correlation between the ETS score and "social competence" subscale score. As the "social competence" subscale score increased, the ETS score also increased. Five subscale scores included in the multiple linear regression analysis explained $19.6 \%$ of the change in ETS scores. Independently of the other variables, the "social competence" subscale score explained $18.3 \%$ of the change in ETS scores (Table IV).

Table 4. Results of multiple linear regression analysis regarding the variables predicting empathic tendency scale score

\begin{tabular}{|l|l|l|l|l|l|}
\hline Variable & \multicolumn{2}{|l|}{$\begin{array}{l}\text { Non-standardized } \\
\text { Coefficients }\end{array}$} & $\begin{array}{l}\text { Standardized } \\
\text { Coefficients }\end{array}$ & & \\
\hline & $\mathrm{B}$ & $\begin{array}{l}\text { Standard } \\
\text { Error }\end{array}$ & Beta & $\mathrm{t}$ & $\mathrm{p}$ \\
\hline Invariant & 47.351 & 5.776 & & 8.198 & $<0.001$ \\
\hline $\begin{array}{l}\text { Social Competence } \\
\text { Score }\end{array}$ & 0.836 & 0.251 & 0.369 & 3.332 & 0.001 \\
\hline $\begin{array}{l}\text { Social Resources } \\
\text { Score }\end{array}$ & 0.062 & 0.203 & 0.036 & 0.306 & 0.760 \\
\hline $\begin{array}{l}\text { Perception of } \\
\text { Future Score }\end{array}$ & 0.192 & 0.224 & 0.088 & 1.859 & 0.392 \\
\hline $\begin{array}{l}\text { Family Cohesion } \\
\text { Score }\end{array}$ & -0.040 & 0.163 & -0.025 & 0.243 & 0.808 \\
\hline $\begin{array}{l}\text { Perception of Self } \\
\text { Score }\end{array}$ & 0.114 & 0.202 & 0.057 & 0.565 & \\
\hline
\end{tabular}

Dependent variable: Empathic Tendency Scale Score, B is the nonstandardized beta $(B)$ value. This value shows how many units the dependent variable increases with each unit increment of the predictor variable

\section{DISCUSSION}

Considering that much has been studied in the literature $(1,3,10-13,21,22,24-26,30-36)$; nurses are expected to be empathic and resilient. Upon examining the literature, the risk and protective factors related to resilience for sustaining, maintaining and improving psychological resilience have been defined, and in many studies, the resilience level, the factors affecting resilience and the results of resilience have been investigated $(1,3,8-26)$. However, there were few studies which the relationship between resilience and empathy were investigated (23-25).

Empathy is an important component of nursing care and therapeutic relationship, which influences the quality of care (30). The literature indicates nurses' mean empathic tendency scores range between 65.95 and 77.43 (31-35). This study found nurses' mean empathic tendency scores were $70.03 \pm 7.89$, which complies with the literature.

The literature indicates various levels of resilience for nurses $(1,12,21,22,24,25)$. Rocha et al. (21) conducted a study with 56 psychiatric nurses in Brazil and found that $50 \%$ of the nurses had a high level of resilience and $42.9 \%$ of the nurses had a moderate level of resilience. Guo et al. (22) found that 1061 nurses in China had a moderate level of resilience. Navarro-Abal et al. (23) found that 128 nursing assistants had a moderate level of resilience. Matos et al. (1) found the resilience level of 32 psychiatric nurses was moderate. Zheng et al. (12) found the resilience level of 726 psychiatric nurses was low. Öksüz et al. (24), who used the same scale as this study, found the resilience level of 242 nurses was

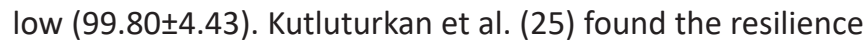
level of 148 oncologic nurses was high (median: 134.0, min: 122, max: 146.0). However, this study found that $64 \%$ of the nurses had a resilience score above average (126.84 \pm 16.08 ). The study results are different from the literature, perhaps because this study used different measurement tools and/ or the nurses in the sample were working in different departments. However, in their qualitative study, Marie et al. (26) found that religious and cultural resources of the nurses working in the community mental health workplaces in Palestine had a significant role in their resilience. Nurses stated that political conflicts in Palestine made them receive support from spiritual values and become more determined, patient, and resilient in coping with difficulties. Accordingly, various studies conducted in different countries indicate that resilience may differ by groups with different experiences, cultures, and spiritual values.

This study found the psychiatric nurses' resilience and empathic tendencies were above the median value. In addition, psychiatric nurses with higher resilience were more empathic. Akbaş (18) examined the relationship between resilience and empathic tendency in families with special needs children, and found a positive relationship. 
Morice-Ramat, Goronflot and Guihard (2018) conduct a study to explore resilience, resilience predicting factors and resilience distribution in French medical residents. They found the resilience and empathy were positively correlated (19). These findings are similar to this study.

Mathad, Pradhan and Rajesh (2017) have found a positive correlation between nursing students' resilience and empathy, but empathy has not been a predictor of resilience (20). McFarland and Roth (2016) examined the relationship between the resilience of physician assistants working in hematology and oncology clinics and their level of stress and empathy. They found that their resilience was negatively related to their stress levels, but it was not related to their level of empathy (17). This outcome was related to the following: both resilience and empathy were structural characteristics that were hard to measure. Vinayak and Judge (37) examined the relationship between psychological well-being and resilience and empathy in adolescents. They found that both empathy and resilience were predictors of the psychological well-being of female participants. Being empathetic and trying to understand others, protects the psychological well-being of individuals (37). This indicates that empathy toughens the individual psychologically.

In this study there has been found positive correlations between ETS and 3 subscales of the psychological resilience (perception of future, social competence and social resources). According to these findings multiple linear regression analysis was carried out to find the predictors of ETS. It has been found that social competence predicts ETS of psychiatric nurses. Accordingly, nurses who were supported with their resilience and social competences (sincerity and flexibility in their social relationships, ability to make friends easily and use humor positively, etc.) tended to be empathic. In the literature review, similar results were found with our study. McAllister and McKinnon (2009) indicated that resilient individuals could sustain their friendships for a longer time, gave emotional support, had a better relationship with family and friends, and utilized social support resources when needed (38). Avcl, Aydın \& Özbaşaran (36) found a positive relationship between altruism levels and empathic tendencies of 218 nursing students. In addition, altruism levels of students who did not have close friends were low. This situation was interpreted as follows: a growing social relationship network would increase helping behavior or would extend the relationship network of this behavior. Patterson (2002) (14) and Lietz $(2007,2011)(15,16)$ also found that families' resilience levels were related to helping and empathizing with other individuals experiencing similar problems. Morice-Ramat et al. (2018) found empathy is a predictor of resilience (19). According to all these findings $(9,14-17,19)$, it can be indicated that resilience and empathy mutually affect each other. However, this study emerged that, the social competence of psychiatric nurses, which is the component of the psychological resilience, is a predictor of empathy.

\section{CONCLUSION}

This study found the psychiatric nurses' resilience and empathic tendencies were above the median value. Both empathy and resilience should be improved because they are significant in preserving and improving the psychology of nurses with stressful working conditions. Psychiatric nurses' resiliences' and social competencies' is a predictor of their empathic tendencies's. Therefore, we recommend enacting regulations to improve resilience and empathic tendencies of psychiatric nurses in in-service trainings and certification programs; increasing awareness of the importance of resilience and empathy; allowing communication skills programs (role-play, psychodrama, etc.) to improve empathy and social competence, which is related to empathy; allowing for organizational activities; arranging in-house and inter-institutions meetings; structuring education programs for nursing students' to improve their social competence, empathy, and resilience; and conducting descriptive and experimental studies in larger groups to determine the preventive factors affecting the improvement of nurses' resilience.

\subsection{Limitations And Strengths}

The present study was conducted for two months in only one hospital because of practical difficulties, time constraints, and economic limitations. Situations that could result from the organization that might affect nurses' resilience were ignored because it was conducted at one center. Reaching the entire population was aimed. Thus, the sample was chosen using the "improbable sampling" method, which is a "random sampling" method. Thus, the generalizability of the data is limited. In addition, possibilities of nurses' evaluating expressions under the influence of social likability should not be ignored.

Conducting new studies in different provinces, hospitals, and regions using similar scales in this field will contribute to the reliability and validity of the study. Empathic tendency which is a preventive factor of resilience and a characteristic a nurse should have positively affects resilience. This study revealed the relationship between resilience and empathic tendency, thereby contributing to the limited relevant literature. In addition, this study sheds light on studies to be conducted regarding nurses' resilience and empathetic tendency.

\section{REFERENCES}

[1] Matos PS, Neushotz LA, Griffin MTQ, Fitzpatrick JJ. An exploratory study of resilience and job satisfaction among psychiatric nurses working in inpatient units. Int J Ment Health Nurs 2010; 19(5):307-312.

[2] Jalil R, Huber J, Sixsmith J, Dickens G. Mental health nurses' emotions, exposure to patient aggression, attitudes to and use of coercive measures: Cross sectional questionnaire survey. Int J Nurs Stud 2017; 75:130-138.

[3] Warelow P, Edward K. Caring as a resilient practice in mental health nursing. Int J Ment Health Nurs 2007; 16(2):132-135. 
[4] Tonso MA, Prematunga RK, Norris SJ, Williams L, Sands N, Elsom SJ. Workplace violence in mental health: A Victorian Mental Health Workforce Survey. Int J Ment Health Nurs 2016; 25(5):444-451.

[5] Edward K, Hercelinskyj G, Giandinoto JA. Emotional labour in mental health nursing: An integrative systematic review. Int J Ment Health Nurs 2017; 26(3):215-225.

[6] Jacobowitz W. PTSD in psychiatric nurses and other mental health providers: A review of the literature. Issues Ment Health Nurs 2013; 34(11):787-795.

[7] Pearson GS. Psychiatric nurses and secondary trauma. Perspect Psychiatr Care 2012; 48(3):123-124.

[8] Roche M, Duffield C, White E. Factors in the practice environment of nurses working in inpatient mental health: A partial least squares path modeling approach. Int J Nurs Stud 2011; 48(12):1475-1486.

[9] Çam O, Büyükbayram A. Nurses' resilience and effective factors. J. Psychiatr. Nurs. 2017; 8(2):118-126.

[10] Ramirez ME. Resilience: a concept analysis. Nurs Forum, 2007; 42(2):73-82.

[11] Cleary M, Jackson D, Hungerford CL. Mental health nursing in Australia: resilience as a means of sustaining the specialty. Issues Ment Health Nurs 2013; 35(1):33-40.

[12] Zheng Z, Gangaram P, Xie H, Chua S, Ong SBC, Koh SE. Job satisfaction and resilience in psychiatric nurses: A study at the Institute of Mental Health, Singapore. Int J Ment Health Nurs 2017; 26(6):612-619.

[13] Mealer M, Jones J, Newman J, McFann KK, Rothbaum B, Moss $M$. The presence of resilience is associated with a healthier psychological profile in intensive care unit (ICU) nurses: Results of a national survey. Int J Nurs Stud 2012; 49(3):292-299.

[14] Patterson JM. Understanding family resilience. J Clin Psychol 2002; 58(3):233-246.

[15] Lietz CA. Uncovering stories of family resilience: A mixedmethods study of resilient families. Part 2. Fam Soc 2007; 88(1):147-155.

[16] Lietz CA. Empathic action and family resilience: A narrative examination of the benefits of helping others. J Soc Serv Res 2011; 37(3):254-265.

[17] McFarland DC, Roth A. Resilience of internal medicine house staff and its association with distress and empathy in an oncology setting. Psycho-Oncology 2016; 26(10):1519-1525.

[18] Akbaş S. The relationship between the level of emphatic tendency and resilience for parents of children with special education needs. Nişantaşı University Institute of Social Sciences, Master thesis. 2015. (in Turkish)

[19] Morice-Ramat, A., Goronflot, L., \& Guihard, G.. Are alexithymia and empathy predicting factors of the resilience of medical residents in France?. Int. J. Med. Educ. 2018; 9:122-128.

[20] Mathad, M. D., Pradhan, B., \& Rajesh, S. K. Correlates and Predictors of Resilience among Baccalaureate Nursing Students. J Clin Diagn Res 2017;11(2), JC05-JC08.

[21] Rocha FLR, Gaioli CCL de O, Camelo SHH, Mininel VA, Vegro TC. Organizational culture of a psychiatric hospital and resilience of nursing workers. Rev Bras Enferm 2016; 69(5):765-72.
[22] Guo YF, Cross W, Plummer V, Lam L, Luo YH, Zhang JP. Exploring resilience in Chinese nurses: a cross-sectional study. J Nurs Manag 2017; 25(3):223-230.

[23] Navarro-Abal Y, López-López MJ, Climent-Rodríguez JA. Engagement, resilience and empathy in nursing assistants. Enfermería Clín 2018; 28(2):103-110.

[24] Öksüz E, Demiralp M, Mersin S, Tüzer H, Aksu M, Sarıkoc G. Resilience in nurses in terms of perceived social support, job satisfaction and certain variables. J Nurs Manag 2018; 27(2):423-432.

[25] Kutluturkan S, Sozeri E, Uysal N, Bay F. Resilience and burnout status among nurses working in oncology. Ann Gen Psychiatry 2016; 15(1):1-9.

[26] Marie M, Hannigan B, Jones A. Resilience of nurses who work in community mental health workplaces in Palestine. Int $\mathrm{J}$ Ment Health Nurs 2016; 26(4):344-354.

[27] Dökmen Ü. Empatinin yeni bir modele dayanılarak ölçülmesi ve psikodrama ile gerçekleştirilmesi. Ankara Üniversitesi Eğitim Bilimleri Dergisi, 1988; 2(1-2): 155-90. (in Turkish)

[28] Basım N, Çetin F. Yetişkinler için Psikolojik Dayanıklılık Ölçeği'nin Güvenilirlik ve Geçerlilik Çalışması. Turk Psikiyatri Derg 2011; 22(2):104-114. (in Turkish)

[29] Friborg O, Hjemdal O, Rosenvinge JH, Martinussen M. A new rating scale for adult resilience: what are the central protective resources behind healthy adjustment? International Journal of Methods in Psychiatric Research 2003; 12(2):65-76.

[30] Yu J, Kirk M. Measurement of empathy in nursing research: systematic review. J Adv Nurs 2008; 64(5):440-454.

[31] Polat S, Küçük Alemdar D, Gürol A. Paediatric nurses' experience with death: The effect of empathic tendency on their anxiety levels. Int J Nurs Pract 2013; 19(1):8-13.

[32] Özcan H. Hemşirelerin empatik eğilim ve empatik becerileri: Gümüşhane örneği. Gümüşhane Üniversitesi Sağlık Bilimleri Dergisi 2012; 1(2):60-68. (in Turkish)

[33] Şentürk S, Uçak A. Evaluation of empathic tendency levels of the intensive care unit nurses in terms of various variables. Turkish Journal of Health Science and Life 2018; 1(1):7-13.

[34] Çınarlı T, Koç Z, Duran L. Burnout and empathic tendency levels in emergency nurses. Eurasian J Emerg Med. 2016; 15(4):181186.

[35] Tunç P, Gitmez A, Boothby MRK. Yoğun bakım ve yataklı servis hemşirelerinde duygusal emek stratejilerinin empatik eğilim açısından incelenmesi. Anadolu Psikiyatri Derg 2014; 15:4554. (in Turkish)

[36] Avcı D, Aydın D, Özbaşaran F. Hemşirelik öğrencilerinde empati-özgecilik ilişkisi ve özgeci davranışın bazı değişkenler açısından incelenmesi. Balıkesir Sağlık Bilimleri Dergisi 2013; 2(2):108-113. (in Turkish)

[37] Vinayak S, Judge J. Resilience and empathy as predictors of psychological wellbeing among adolescents. International Journal of Health Sciences and Research 2018; 8(4):192-200.

[38] McAllister M, McKinnon J. The importance of teaching and learning resilience in the health disciplines: A critical review of the literature. Nurse Educ Today 2009; 29(4):371-379. 